\title{
Influence of naphthalene acetic acid (NAA) and integrated nutrient management (INM) on yield and economics attributes of chilli (Capsicum annuum L.)
}

\author{
Amrita Kumari ${ }^{*}$, V. K. Singh ${ }^{1}$, S. Shree ${ }^{1}$, Vikash Kumar ${ }^{2}$ and Vishal Nirgude ${ }^{2}$ \\ ${ }^{1}$ Department of Horticulture (Vegetables and Floriculture), Bihar Agricultural University, Sabour- 813210 (Bihar), INDIA \\ ${ }^{2}$ Department of Horticulture (Fruit \& Fruit Technology), Bihar Agricultural University, Sabour- 813210 (Bihar), INDIA \\ *Corresponding author. E-mail: amritaicar14@gmail.com
}

Received: May 17, 2016; Revised received: October 25, 2016; Accepted: January 29, 2017

\begin{abstract}
The present experiment was conducted to study the response of naphthalene acetic acid NAA and integrated nutrient management on yield and yield attributes as well as and economics of chilli ( Capsicum annuum L.) with four levels of NAA (0 ppm, $25 \mathrm{ppm}, 50 \mathrm{ppm}$ and $75 \mathrm{ppm})$ and five levels of vermicompost (VC) along with RDF $\left(V_{0}-100 \%\right.$ Recommended dose of fertilizer i.e. 120:60:60 Kg N P K /ha ), $V_{1}-100 \%$ N through Vermicompost, $V_{2}-75 \%$ $\mathrm{N}$ through $\mathrm{VC}+25 \%$ (RDF), $\mathrm{V}_{3}-50 \% \mathrm{~N}$ through $\mathrm{VC}+50 \%$ (RDF), $\mathrm{V}_{4}-25 \% \mathrm{~N}$ through $\mathrm{VC}+75 \%$ (RDF), having 20 treatment combinations. The results revealed that the combine application of $50 \mathrm{ppm} N A A$ and $100 \% \mathrm{~N}$ through vermicompost i.e. $\mathrm{P}_{2} \mathrm{~V}_{1}$ performed well in respect of fruit length $(8.73 \mathrm{~cm})$, fruit diameter $(1.46 \mathrm{~cm})$ and fruit weight $(2.91 \mathrm{~g})$ while the application of NAA $50 \mathrm{ppm}+50 \% \mathrm{~N}$ through vermicompost along with $50 \%$ RDF i.e. $\mathrm{P}_{2} \mathrm{~V}_{3}$ gave significantly $(P=0.05)$ maximum number of fruits/plant $(73.86)$ and fruit yield per hectare $(121.20 \mathrm{q})$ with higher gross income (Rs.2,66,640.00/ ha), net profit (Rs.1,98,946.00/ ha) and benefit - cost ratio (2.94). Therefore, it can be concluded that the combine effect of NAA $50 \mathrm{ppm}$ along with $50 \% \mathrm{~N}$ through vermicompost $+50 \%$ inorganic fertilizers (RDF) gave better result regarding growth and yield attributes and also generated maximum gross income, net return and $\mathrm{B}: \mathrm{C}$ ratio while the next best treatment was application of NAA $75 \mathrm{ppm}$ alongwith $25 \% \mathrm{~N}$ through vermicompost $+75 \%$ inorganic fertilizers (RDF).
\end{abstract}

Keywords: Chilli, NAA, RDF, Vermicompost

\section{INTRODUCTION}

Among the solanaceous fruit vegetables chilli (Capsicum annuum L. ) is one of the most valuable commercial vegetable as well as spice crop not only for India but also for all over the world. India is the largest producer, consumer as well as exporter of chilli in the world. In Indian cuisine it has a crucial value for imparting natural colorant and pungent taste in food stuffs. It is a rich source of vitamin A, C and E, whose role as antioxidants is well documented. Cultivation of chilli is increasing day to day due to its greater importance. Chilies one of the exhaustive crop, therefore, it needs greater amount of nutrient application. The chemical fertilizers, of course increased the vegetable production but they decreased soil fertility, harm the environment and also cause health problems for consumers. Organic manures are excellent source of plant available nutrients and their addition to soil could maintain high microbial population and their activities (Joshi and Vig, 2010). Hence, adoption of integrated use of organic and inorganic fertilizers offers scope for sustainable crop production (Lal and Kanaujia, 2013). Vermicompost has been found to be an ideal organic source of minerals, macro and micro nutrients, plant growth hormones (IAA, IBA and GA), vitamins, enzymes and many beneficial microbes and releases nutrients slowly for absorption with additional nutrients which help to increase yield (Hidalgo and Pashanasi, 1999). The increase fruit drop, decrease percentage of fruit set, more vegetative growth and delay in flowering are the major issues which lead to lower production and productivity of chilli (Erickson and Makhart, 2001) and Balraj et al. (2002). NAA improves the internal physiology of plants in terms of better supply of water, nutrients and other bio-compounds vital for their proper growth and development (Meena and Dhaka, 2003) and Khurana et al. (2004).Such efforts will be effective not only in sustaining productivity on soil health but also in curtailing a part of chemical fertilizers requirement of the crop. Keeping all the facts under consideration and visualising the paucity of information on these aspects for agroclimatic condition of Bihar. In view of the above facts, the investigation was undertaken to find out the response of NAA and integrated nutrient management on yield attributes and economics of chilli.

\section{MATERIALS AND METHODS}

The field experiment was conducted at Bihar Agricultural College, Sabour during summer season 2014-15. The 
experiment was laid out in a factorial randomized block design, replicated three times with the variety 'Jawaher Mirch 218'. The treatments used were Naphthalene Acetic acid (NAA), vermicompost (VC) as organic manure and inorganic fertilizers such as urea, single super phosphate (SSP) and murate of potash (MOP). There were four levels of NAA ( $\mathrm{P}_{0}-0$ ppm, $\mathrm{P}_{1}-25 \mathrm{ppm}, \mathrm{P}_{2^{-}}-50 \mathrm{ppm}$ and $\left.\mathrm{P}_{3^{-}}-75 \mathrm{ppm}\right)$ and five levels of vermicompost along with $\mathrm{RDF}\left(\mathrm{V}_{0}-100 \%\right.$ Recommended dose of fertilizers i.e. 120:60:60 Kg N $\mathrm{P} \mathrm{K} / \mathrm{ha}), \mathrm{V}_{1^{-}}(100 \% \mathrm{~N}$ through Vermicompost), $\mathrm{V}_{2^{-}}(75 \% \mathrm{~N}$ through $\mathrm{VC}+25 \% \mathrm{RDF}), \mathrm{V}_{3^{-}}(50 \% \mathrm{~N}$ through $\mathrm{VC}+50 \% \mathrm{RDF})$ and $\mathrm{V}_{4}-(25 \% \mathrm{~N}$ through $\mathrm{VC}$ $+75 \%$ RDF) having 20 treatment combinations. The soil of the experimental plot was sandy loam in texture having $\mathrm{pH} 7.8$, organic carbon $(0.42 \%)$, available nitrogen $(125.11 \mathrm{~kg} / \mathrm{ha})$, phosphorus $(26.28 \mathrm{~kg} / \mathrm{ha})$ and potassium $(206.18 \mathrm{~kg} / \mathrm{ha})$ and as per the method suggested by Schofield and Taylor (1965),Piper (1950),Jackson (1963), Olsen method (1954) and Toth and Prince (1944) respectively. Treatment wise vermicompost and full dose of $\mathrm{P}_{2} \mathrm{O}_{5}$ and $\mathrm{K}_{2} \mathrm{O}$ as well as $1 / 3^{\text {rd }}$ dose of nitrogen were applied and mixed thoroughly and then plots were dressed for transplanting. Well-developed healthy seedling attaining an age of 35 days were uprooted from the nursery and transplanted in the evening with a spacing $50 \mathrm{~cm} \times 30 \mathrm{~cm}$. First top dressing of $1 / 3^{\text {rd }} \mathrm{N}$ as urea was done after 20 days after transplanting and $2^{\text {nd }}$ top dressing was done 50 days after transplanting. The treatment wise NAA was sprayed in each plot early in the morning when dews had evaporated. The spraying was performed with the help of knapsack sprayer. First sprayed was done after 35 days after transplanting and second was at the time of flowering. Plant protection measure and other cultural practices were followed as per need of the crop. The observations were recorded on yield attributing characters like number of fruits per plant, fruit length, fruit diameter, fruit weight and fruit yield per plant and yield (fresh green fruit) $\mathrm{q} / \mathrm{ha}$.

The economics studies of the crop was done by computing the cost of cultivation and net profit in rupees per hectare on the basis of the prevailing rate of inputs and output obtained from the local market. Gross return was calculated by multiplying yield ( $\mathrm{q} / \mathrm{ha}$ ) with average selling rate of chilli fruits. The net return (Rs/ha) was calculated by subtracting the cost of cultivation from the gross return obtained from the sale of the harvested chilli fruits. The benefit -cost ratio i.e. the net return per rupee investment was obtained by dividing net profit with total cost of cultivation.

\section{RESULTS AND DISCUSSION}

It is evident from the results that the NAA and integration of organic and inorganic fertilizers could bring significant result in the production and economics of chilli. The data (Table 1) showed that application of
NAA at $50 \mathrm{ppm}\left(\mathrm{P}_{2}\right)$ gave highest number of fruits (71.33), average fruit length $(8.55 \mathrm{~cm})$, fruit diameter $(1.41 \mathrm{~cm})$, fruit weight $(2.81 \mathrm{~g})$, fruit yield per plant $(202.53 \mathrm{~g})$ and yield per hectare $(108.39 \mathrm{q} / \mathrm{ha})$ which was at par with NAA $75 \mathrm{ppm}\left(\mathrm{P}_{3}\right)$ except for fruit length, diameter and weight. The increase in fruit length and diameter might be attributed to increase in the number of cells as well as elongation of cells which are the characteristic action of NAA. These results are supported by Kannan et al. (2009) on Paprika cv. KtPl-19.They found that maximum yield attributing characters were achieved by the treatment of NAA 50 ppm during both winter and summer season.. Better performance of NAA might be also due to proper growth of plants, control of abscission layer in full bloom stage which hasten the fruit setting and increased in number of fruits, ultimately enhanced yield. These results are also in close agreement with earlier findings of Khurana et al. (2004), They reported that higher yield of chilli was achieved by after spray of NAA, similar results were found by Veishnav et al. (2012) with the foliar application of 40 ppm NAA.

Integration of organic and inorganic fertilizers augmented the yield and yield attributing characters. Treatment $\mathrm{V}_{1}(100 \% \mathrm{~N}$ through $\mathrm{VC})$ produced maximum fruit length $(8.67 \mathrm{~cm})$, fruit diameter $(1.36$ $\mathrm{cm})$ and fruit weight $(2.78 \mathrm{~g})$ and found significantly superior to the rest levels of vermicompost along with RDF. This might be due to sole application of vermicompost caused shorter plant, lesser number of branches which ultimately produced less number of fruits so the synthesized food material which were later translocated into developing fruits resulting in increased fruit length, fruit diameter and fruit weight. These results are also supported by Sinha et al. (2010 b) reported that vermicompost improved yield parameters of Egg plant and similar results were also found by Azarmi et al. (2008) in tomato. However, maximum number of fruit (69.36), fruit yield per plant (184.69 $\mathrm{g})$, fresh green fruit yield $(102.46 \mathrm{q} / \mathrm{ha})$ were recorded $\operatorname{inV}_{3}(50 \% \mathrm{~N}$ through VC $+50 \% \mathrm{RDF})$. The possible reason for increased fruit yield was attributed to the solubilization effect and availability of nutrients by the addition of vermicompost (Edwards and Bohlen, 1996 and Parthasarathi, 2010). The adequate amount of inorganic fertilizers, effectively maintain the physiology of plant which reduces the fruit drop and increases the number of fruits, ultimately increase in yield. These results are in conformity with earlier finding of Sha and Karuppiah (2010). They reported that combined application of vermicompost $(7.5 \mathrm{t} / \mathrm{h})$, recommended dose of N P K (160:60:60 Kg/h) along with foliar spray of micronutrient mixture $(0.25 \%)$ enhanced yield and yield parameters of chilli. Similar results were reported by Mohd Rafi et al. (2002) in tomato and Shashidhara (2000), Hangarge et al. (2002) in chilli. 
Amrita Kumari et al. / J. Appl. \& Nat. Sci. 9 (1): 311 - 315 (2017)

Table 1. Effect of levels of NAA and vermicompost along with RDF on yield attributes of chilli during 2014-15.

\begin{tabular}{|c|c|c|c|c|c|c|}
\hline Levels of NAA & $\begin{array}{c}\text { Number of } \\
\text { Fruits / } \\
\text { Plant } \\
\end{array}$ & $\begin{array}{c}\text { Fruit } \\
\text { Length } \\
\text { (cm) }\end{array}$ & $\begin{array}{c}\text { Fruit } \\
\text { Diameter } \\
(\mathbf{c m}) \\
\end{array}$ & $\begin{array}{c}\text { Fruit } \\
\text { Weight } \\
\text { (g) } \\
\end{array}$ & $\begin{array}{l}\text { Fruit Yield/ } \\
\text { Plant (g) }\end{array}$ & $\begin{array}{l}\text { Fresh Yield } \\
\qquad(q / \text { ha })\end{array}$ \\
\hline $\mathrm{P}_{0}(0 \mathrm{ppm})$ & 55.66 & 7.85 & 1.12 & 2.11 & 119.09 & 66.03 \\
\hline $\mathrm{P}_{1}(25 \mathrm{ppm})$ & 65.00 & 8.15 & 1.23 & 2.61 & 162.57 & 88.87 \\
\hline $\mathrm{P}_{2}(50 \mathrm{ppm})$ & 71.33 & 8.55 & 1.41 & 2.81 & 202.53 & 108.39 \\
\hline $\mathrm{P}_{3}(75 \mathrm{ppm})$ & 69.44 & 8.47 & 1.38 & 2.79 & 196.65 & 104.84 \\
\hline $\mathrm{CD}$ at $5 \%$ & 0.61 & 0.08 & 0.01 & 0.03 & 1.80 & 0.95 \\
\hline \multicolumn{7}{|c|}{ Levels of Vermicompost along with RDF } \\
\hline $\mathrm{V}_{0}(100 \% \mathrm{RDF})$ & 58.50 & 7.77 & 1.18 & 2.44 & 147.58 & 76.52 \\
\hline $\mathrm{V}_{1}(100 \% \mathrm{~N}$ through $\mathrm{VC})$ & 60.40 & 8.67 & 1.36 & 2.78 & 164.35 & 90.30 \\
\hline $\begin{array}{l}\mathrm{V}_{2}(75 \% \mathrm{~N} \text { through } \mathrm{VC}+ \\
25 \% \mathrm{RDF}\end{array}$ & 66.65 & 8.45 & 1.33 & 2.63 & 178.60 & 97.61 \\
\hline $\begin{array}{l}\mathrm{V}_{3}(50 \% \mathrm{~N} \text { through } \mathrm{VC}+ \\
50 \% \mathrm{RDF})\end{array}$ & 69.36 & 8.17 & 1.26 & 2.59 & 184.69 & 102.46 \\
\hline $\begin{array}{l}\mathrm{V}_{4}(25 \% \mathrm{~N} \text { through } \mathrm{VC} \\
+75 \% \mathrm{RDF})\end{array}$ & 67.88 & 8.20 & 1.26 & 2.46 & 175.82 & 93.26 \\
\hline $\mathrm{CV}$ at $5 \%$ & 0.76 & 0.09 & 0.01 & 0.03 & 2.25 & 1.19 \\
\hline
\end{tabular}

Table 2. Combined effect of NAA and vermicompost along with RDF on yield attributes during 2014-15 of chilli.

\begin{tabular}{|c|c|c|c|c|c|c|}
\hline $\mathbf{P X V}$ & $\begin{array}{l}\text { Number of } \\
\text { fruits/plant }\end{array}$ & $\begin{array}{l}\text { Fruit length } \\
(\mathrm{cm})\end{array}$ & $\begin{array}{l}\text { Fruit diameter } \\
(\text { (cm) }\end{array}$ & $\begin{array}{c}\text { Fruit weight } \\
\text { (g) }\end{array}$ & $\begin{array}{l}\text { Fruit yield/ } \\
\text { Plant (g) }\end{array}$ & $\begin{array}{l}\text { Fresh yield } \\
\text { (q/ ha) }\end{array}$ \\
\hline P0V0 & 47.33 & 6.67 & 0.85 & 1.76 & 94.53 & 54.51 \\
\hline P0V1 & 52.40 & 8.59 & 1.27 & 2.56 & 107.28 & 60.46 \\
\hline P0V2 & 56.40 & 8.25 & 1.20 & 2.25 & 126.90 & 69.37 \\
\hline P0V3 & 61.80 & 7.98 & 1.16 & 2.18 & 134.72 & 73.64 \\
\hline P0V4 & 60.40 & 7.76 & 1.13 & 1.80 & 132.05 & 72.18 \\
\hline P1V0 & 52.86 & 7.36 & 1.14 & 2.53 & 127.53 & 69.72 \\
\hline P1V1 & 65.40 & 8.69 & 1.29 & 2.77 & 149.16 & 81.54 \\
\hline P1V2 & 68.40 & 8.37 & 1.30 & 2.62 & 179.21 & 97.96 \\
\hline P1V3 & 70.60 & 8.20 & 1.24 & 2.60 & 183.56 & 100.34 \\
\hline P1V4 & 67.73 & 8.12 & 1.20 & 2.55 & 173.39 & 94.78 \\
\hline $\mathrm{P} 2 \mathrm{~V} 0$ & 68.20 & 8.59 & 1.38 & 2.75 & 186. 04 & 91.20 \\
\hline P2V1 & 70.40 & 8.73 & 1.46 & 2.91 & 204.42 & 111.75 \\
\hline $\mathrm{P} 2 \mathrm{~V} 2$ & 71.60 & 8.62 & 1.42 & 2.85 & 208.06 & 113.73 \\
\hline $\mathrm{P} 2 \mathrm{~V} 3$ & 73.86 & 8.31 & 1.40 & 2.80 & 212.30 & 121.20 \\
\hline P2V4 & 72.60 & 8.49 & 1.39 & 2.76 & 201.83 & 104.08 \\
\hline P3V0 & 65.60 & 8.46 & 1.35 & 2.73 & 182.23 & 90.66 \\
\hline P3V1 & 69.20 & 8.68 & 1.44 & 2.87 & 196.57 & 107.45 \\
\hline P3V2 & 70.20 & 8.58 & 1.38 & 2.81 & 200.26 & 109.40 \\
\hline P3V3 & 71.20 & 8.19 & 1.35 & 2.78 & 208.19 & 114.66 \\
\hline P3V4 & 70.80 & 8.45 & 1.35 & 2.74 & 196.03 & 102.00 \\
\hline $\mathrm{CD}$ at $5 \%$ & 5.31 & 0.65 & 0.13 & 0.25 & 15.64 & 8.29 \\
\hline
\end{tabular}


Table 3. Combine effect of NAA and vermicompost along with RDF on economics and benefit: cost ratio of Chilli.

\begin{tabular}{lccccc}
\hline PXV & Yield (q/ ha) & $\begin{array}{c}\text { Gross income } \\
\text { (Rs.) }\end{array}$ & $\begin{array}{c}\text { Total cost of } \\
\text { cultivation (Rs.) }\end{array}$ & Net Income (Rs.) & B:C Ratio \\
\hline $\mathrm{P}_{0} \mathrm{~V}_{0}$ & 54.51 & 119922 & 51868 & 68054 & 1.31 \\
$\mathrm{P}_{0} \mathrm{~V}_{1}$ & 60.47 & 133034 & 81616 & 51418 & 0.63 \\
$\mathrm{P}_{0} \mathrm{~V}_{2}$ & 69.37 & 152614 & 74445 & 78169 & 1.05 \\
$\mathrm{P}_{0} \mathrm{~V}_{3}$ & 73.64 & 162008 & 66922 & 95086 & 1.42 \\
$\mathrm{P}_{0} \mathrm{~V}_{4}$ & 72.18 & 158796 & 59391 & 99405 & 1.67 \\
$\mathrm{P}_{1} \mathrm{~V}_{0}$ & 69.72 & 153384 & 52430 & 100954 & 1.92 \\
$\mathrm{P}_{1} \mathrm{~V}_{1}$ & 81.54 & 179388 & 82178 & 97210 & 1.18 \\
$\mathrm{P}_{1} \mathrm{~V}_{2}$ & 97.96 & 215512 & 75007 & 140505 & 1.87 \\
$\mathrm{P}_{1} \mathrm{~V}_{3}$ & 100.34 & 220748 & 67484 & 153264 & 2.27 \\
$\mathrm{P}_{1} \mathrm{~V}_{4}$ & 94.78 & 208516 & 59953 & 148563 & 2.47 \\
$\mathrm{P}_{2} \mathrm{~V}_{0}$ & 91.20 & 200640 & 52640 & 148000 & 2.81 \\
$\mathrm{P}_{2} \mathrm{~V}_{1}$ & 111.75 & 245850 & 82388 & 163462 & 1.98 \\
$\mathrm{P}_{2} \mathrm{~V}_{2}$ & 113.73 & 250206 & 75217 & 174989 & 2.32 \\
$\mathrm{P}_{2} \mathrm{~V}_{3}$ & 121.20 & 266640 & 67694 & 198946 & 2.93 \\
$\mathrm{P}_{2} \mathrm{~V}_{4}$ & 104.08 & 228976 & 60163 & 168813 & 2.80 \\
$\mathrm{P}_{3} \mathrm{~V}_{0}$ & 90.66 & 199452 & 52850 & 146602 & 2.77 \\
$\mathrm{P}_{3} \mathrm{~V}_{1}$ & 107.45 & 236390 & 82598 & 153792 & 1.86 \\
$\mathrm{P}_{3} \mathrm{~V}_{2}$ & 109.4 & 240680 & 75427 & 165253 & 2.19 \\
$\mathrm{P}_{3} \mathrm{~V}_{3}$ & 113.8 & 250360 & 67904 & 182456 & 2.68 \\
$\mathrm{P}_{3} \mathrm{~V}_{4}$ & 102 & 224400 & 60397 & 164003 & 2.71 \\
\hline
\end{tabular}

The interaction effects between plant growth regulator (NAA) and vermicompost along with RDF levels were found to be quite superior to their individual effect. The data (Table 2) revealed that significantly maximum number of fruits (73.86), fruit yield per plant $(212.30 \mathrm{~g})$ and fresh yield per hectare (121.20 q) were produced by the combine application of $50 \mathrm{ppm}$ NAA along with $50 \% \mathrm{~N}$ through $\mathrm{VC}+50 \% \mathrm{RDF}$ i.e. $\mathrm{P}_{2} \mathrm{~V}_{3}$. This might be due to the fact that combine application of organic and inorganic fertilizers provide sufficient nutrients to plant for proper growth and development and plant growth regulator (NAA) reduces the fruit drop, increases the fruit setting as well as enhances the mobilization of photo assimilates at a faster rate which increase number of fruits and ultimately increase in yield. These findings are in agreement with the results of Kalshyam et al. (2011). Who noted; combine application of NAA and fertilizer $(75 \mathrm{ppm} \mathrm{NAA}+150 \mathrm{Kg}$ $\mathrm{N} / \mathrm{h}$ ) gave higher yield and its component in chilli cv. Pusa Jwala. Similar results also were found by of Singh and Mukherjee (2002) in chilli.. The foliar application of NAA $50 \mathrm{ppm}\left(\mathrm{P}_{2}\right)+100 \% \mathrm{~N}$ supplied through vermicompost $(\mathrm{V} 1)$ i.e. $\mathrm{P}_{2} \mathrm{~V}_{1}$ gave significantly maximum fruit length $(8.73 \mathrm{~cm})$ and fruit diameter
$(1.46 \mathrm{~cm})$. This might be due to the fact that the vermicompost is a rich mixture of major and minor plant nutrients and increased microbial activity, improve the availability of soil phosphorus and nitrogen to plant which help in cell division, hence increase in length and diameter of fruits.

Economics: The interaction effect between NAA and vermicompost along with inorganic fertilizers was found beneficial. The net profit per hectare ranged from Rs.51, 418.00 to Rs. 1, 98,946.00 (Table 3). The highest net profit (Rs.1,98,946.00/ ha) was obtained by the foliar application of $50 \mathrm{ppm} \mathrm{NAA}+50 \% \mathrm{VC}$ $+50 \% \mathrm{RDF}\left(\mathrm{P}_{2} \mathrm{~V}_{3}\right)$ while $100 \% \mathrm{~N}$ through vermicomposting the absence of NAA i.e. $\mathrm{P}_{0} \mathrm{~V}_{1}$ gave least net profit (Rs.51,418.00). The benefit-cost ratio ranged from 0.63 to 2.93 depending upon the treatment and it was found to be highest (2.93) by the foliar application of $50 \mathrm{ppm} \mathrm{NAA}+50 \% \mathrm{VC}+50 \% \mathrm{RDF}$ i.e. $\left(\mathrm{P}_{2} \mathrm{~V}_{3}\right)$ followed by 50 ppm NAA $+25 \% \mathrm{~N}$ through $\mathrm{VC}+75 \%$ RDF i.e. $\mathrm{P}_{2} \mathrm{~V}_{4}$ with 2.80 benefit - cost ratio of 2.80. Our results get support from the finding of Singh et al. (2015). Who obtained maximum net profit with application of NAA $50 \mathrm{ppm}$ in chilli. Samsangheile and Kanaujia (2014) also found highest net 
return and benefit-cost ratio with integrated nutrient management in chilli.

\section{Conclusion}

The combine application of 50 ppm NAA and $100 \% \mathrm{~N}$ through vermicompost i.e. $\mathrm{P}_{2} \mathrm{~V}_{1}$ performed well in respect of fruit length $(8.73 \mathrm{~cm})$, fruit diameter $(1.46 \mathrm{~cm})$ and fruit weight $(2.91 \mathrm{~g})$ while the application of NAA $50 \mathrm{ppm}+50 \% \mathrm{~N}$ through vermicompost along with $50 \%$ RDF i.e. $\mathrm{P}_{2} \mathrm{~V}_{3}$ gave significantly (at 5\%) maximum number of fruits/plant (73.86) and fruit yield per hectare $(121.20 \mathrm{q})$ with higher gross income (Rs.2,66,640.00/ha), net profit (Rs.1,98,946.00/ha) and benefit - cost ratio (2.94).

Hence on the basis of these finding it may be concluded that the combine effect of NAA $50 \mathrm{ppm}$ along with $50 \% \mathrm{~N}$ through vermicompost $+50 \%$ inorganic fertilizers (RDF) gave better result regarding growth yield and quality attributes and also generated maximum gross income, net return and $\mathrm{B}: \mathrm{C}$ ratio where as application of NAA $75 \mathrm{ppm}$ along with $25 \% \mathrm{~N}$ through vermicompost $+75 \%$ inorganic fertilizers (RDF) ranked $2^{\text {nd }}$ in marit.

\section{ACKNOWLEDGEMENTS}

The authors thank Chairman of Department of Horticulture (Vegetables and Floriculture), Bihar Agricultural College, Bihar Agricultural University, Sabour, India for providing all the required infrastructure and facilities for the present work.

\section{REFERENCES}

Azarmi, R., Giglou, M. T. and Taleshmikail, R. D. (2008). Influence of vermicopost on soil chemical and physical properties in tomato field. African J. of Biotechnology, 7 (14): 2397-2401

Balraj, R., Kurdikeri, M.B. and Revanappa (2002). Effect of growth regulators on growth and yield of chilli (Capsicum annuum L.) at different pickings. Ind. J. Hort., 59 (1): 84-88.

Edwards, C.A. and Bohlen, P. J. (1996). Biology and Ecology of Earthworms, Chapman and Hall, London

Erickson, A.N. and Markhart, A.H. (2001). Flower production, fruit set and physiology of bell pepper during elevated temperature and vapor pressure deficit. J. Amer. Soc. Hort. Sci., 126 (6): 697-702.

Hangarge, D.S., Ravt, R.S., More, S.D and Brijdhar, R.R. (2002). Response of chilli to integrated nutrient supply system. J. Soil Crops, 10 (2): 188-192

Hidalgo and Pashanasi (1999). Earthworm casting increase germination rate and seedling development of cucumber. Mississipi and Forestry Experiment Station, Research Report 22 No.6.

Jackson, M. L.1963. Nitrogen determination for soil and plant tissues. Prentics Hall of India Pvt. Ltd. New Delhi, India

Joshi, R and Vig, A.P. (2010). Effect of vermicompost on growth, yield and quality of tomato (Lycopersicum esculentum L). Afric. J. Basic Appl. Sci., 2 (3-4): 117-123
Kalshyam, M.K., Kumar, Jitendra, Mohan, B., Singh, J.P., Nathram and Rajbeer (2011). Effect of plant growth hormone and fertilizer on growth and yield parameters in chilli (Capsicum annuum L.) cv. Pusa Jwala. Asian J. Hort., 6 (2): 316-318

Kannan, K., Jawaharlal, M. and Prabhu, M. (2009). Effect of plant growth regulators and yield parameters of Paprika cv. KtPl-19. Agric. Sci. Digest, 29 (3): 157-162

Khurana, D.S., Manchanda, D. and Singh, K. (2004). Influence of naphalene acetic acid on growth and fruit yield of chilli. Haryana J. Hort. Sci., 33 (3/4): 274-275

Lal, S. and Kanaujia, S.P. (2013). Integrated nutrient management in capsicum under low cost polyhouse condition. Ann. Hort., 6: 170-177

Meena, S.S and Dhaka, R.S. (2003). Economics of plant growth regulators in brinjal (Solanum melogena L.) under semiarid condition of Rajasthan. Ann. Agric. Res., 24 (2): 273-275

Mohd Rafi, Narwadkar, P., Prabhu, R. and Sasindrasanath, A.K. (2002). Effect of organic and inorganic sources of fertilizer on growth, and yield of tomato (Lycopersicon esculentum Mill). South Ind. Hort., 50 (4-6): 522-526

Olsen, S. R., Kole, C. V., Watenable, F. S and Dean, L. A. 1954. Estimation of available phosphorus in soil by extraction with sodium bicarbonate. U. S. Deptt. Cire. p. 939

Parthasarathi, K, (2010). Earthworm -Life cycle, Compost and Therapy. Lam Lambert Academic Publishing Ag \& Co. KC. Germany.

Piper, C. S.1950. Soil and plant analysis. The University of Adelaide p. 368

Samsangheile and Kanajia, S.P. (2014). Integrated nutrient management for quality production of chilli on acid alfisol. Ann. Plant Soil Res., 16 (2): 164-167

Schofield, R. K. and Taylor, A. V. 1965. The measurement of soil pH. Proc. of Soil Soc. of America. 19: 164-167

Sha, K. and Karuppiah (2010). Integrated nutrient management on growth, yield and quality of chilli cv K2. Plant Archives, 10(1):371-374

Shashidhara, G.B. (2000). Integrated nutrient management in chilli (Capsicum annuum L.) northern transitional zone of Karnataka. Ph. D. Thesis, University of Agriculture Science, Dharwad.

Singh, D.K., Rudra, B.C., Das, B. and Gangopadhyay P.K. (2015). Effect of Naphthalene Acetic Acid on Yield of Chilli (Capsicum annuum L.). J. Agric. Technol., 2 (1\&2): $84-86$

Singh, L. and Mukherjee, S. (2000). Effect of foliar application of urea and NAA on yield and yield attributes of chilli (Capsicum annuum var: longum). J. Agric. Sci. Digest, 20 (2): 116-117

Sinha, R. K., Valani, D., Chauhan, K and Agarwal, S. (2010b). Embarking on a second green revolution for sustainable agriculture by vermiculture biotechnology using earthworms: Reviving the dreams of Sir Charles Darwin. Agric. Sci., 2(7):113-128

Toth, S. S. and Prince A. C. 1944. Estimation of cation exchange capacity and exchanangeable $\mathrm{K}, \mathrm{Ca}$, and $\mathrm{Na}$ contact of soil by flame photometric technique. Soil Sci. 67: 439-445

Veishnav, N., Singh, B. K. and Singh, A.K. (2012). Effect of NAA on growth \& yield of chilli. Environment and Ecology, 30(4):1261-1263 